\title{
GOVERNMENT-SPONSORED RESEARCH IN THE UNITED STATES
}

$\mathrm{T}$

HE National Science Foundation's report* on Government-University Relationships in Federally Sponsored Scientific Research and Development includes a lucid summary of the evolution and present character of Federal activities at colleges and universities of the United States. It directs attention to three major trends since 1940, in which period Federal expenditure of some 15 million dollars a year on scientific research and development at colleges and universities has increased to 440 million dollars in the year ending June 30, 1958, probably two-thirds of the total. In this period Federal support has extended from the agricultural sciences to every field of natural science. Secondly, the period has seen the innovation and expansion of federally owned and financed research centres; and thirdly, in contrast to the relative absence of Federal "extramural' financial support of research facilities, a significant part of Federal support ( 265 million dollars in 1957-58) goes for construction or operation of major research facilities. It is anticipated that the research and development activities of the Federal Government will continue to expand and that Federal support of basic research at colleges and universities will continue to increase. Reviewing the effect of Federal sponsorship, the Foundation concludes that while in the present situation research is necessarily given some direction by Federal agencies, this direction has not in general been irksome or detrimental, nor does the Foundation believe that the concentration of Federal funds in the natural sciences has deprived the social sciences and humanities of funds from other sources.

The major interest of the report lies in the principles and practices recommended for future Federal sponsorship. Generally, it is recommended that problems of Government-university relations in the

* National Science Foundation, Washington. Government-University Relationships in Federally Sponsored Scientific Research and Development. Pp. ix +44. (Washington, D.C. : Government Printing
Office, 1958.) 40 cents
Federal support of research at colleges and universities should be explicitly and completely dissociated from the budgetary needs and crises of the institu. tions, and from the general issue of Federal aid to higher education. It is also recommended that Federal funds for the support of such basic research at such institutions should continue to come from a diversity of Federal sources; the importance of simplicity of procedure in making contracts and grants, of promptness in negotiation and payment and of avoiding unilateral action is stressed, and further and continuing study of problems involved in such contracting is urged.

Federal agencies, it is recommended, should consider other alternatives before establishing large-scale applied and development projects within universities, except in certain fields such as engineering, agriculture and medicine, where applied research is frequently closely related to educational objectives. Government-sponsored classified research on college campuses should be reduced to a minimum, and Federal agencies should not agree to reimburse institutions for salaries of faculty members engaged in Government-sponsored research at rates in excess of the university-rate, though this should not apply to faculty members granted leave of absence to serve at research centres. Federal agencies should have legal authority to entitle institutions to research equipment procured with grant or contract funds unless a clear and definite need exists for Government control or use of the equipment. It is also recommended that Federal agencies should recognize as appropriate expenditure under research contracts or grants reasonable expenditure on travel to, and participation in, scientific meetings, and that such agencies should be authorized to make contracts or grants for more than one year at their discretion. they should also establish reserves and plan renewal of grants or contracts in advance, to ensure the continuity of support essential for the effective conduct of basic research.

\section{SANDWICH COURSES}

$\mathrm{T}$ HE Association of Teachers in Technical Institutions, in a memorandum on sandwich courses*, which sets out its views on the best way to expand this form of education, objects to the distinction between area colleges and regional colleges in the policy of the Ministry of Education. It regards the virtual restriction of the establishment of new sand. wich courses to colleges of advanced technology and regional colleges as too severe and, considering that works-based courses leave a large field uncovered, recommends wider provision for collegebased students in Britain.

Informal as well as formal co-operation between employers and college staffs are most important, and at the works the trainee should be under the charge of a training officer or senior executive and also in

- Sandwich Courses. Pp. 13. (London: Association of Teachers in Technical Institutions, 1958.) touch with a responsible member of the college staff. The importance of some flexibility in entrance requirements is also stressed, together with the need for active contact with secondary-school headmasters and teachers if students are to be secured. In regard to finance, the Association believes that during his periods of study, unless the firm is prepared to pay him adequate wages, the student should be maintained on the same basis as a full-time student, and it urges that parental income should be ignored in assessing grants.

The memorandum, in stressing the importance of staff of high quality, comments on the conditions of work, which are a continuing source of trouble. The Association urges that if 'end-on' sandwich courses in the same subject running consecutively in one year are essential to industry, they should be run in separate colleges. The Association also believes that 